\title{
Democratic majority principle in trouble?
}

\author{
The example of sustainability conflicts
}

Armin Bangert, Institute for Technology Assessment and Systems Analysis (ITAS), Karlsruhe Institute of Technology (KIT), Karlstr. 11,76133 Karlsruhe (armin.bangert@kit.edu) (1) https://orcid.org/0000-0002-1190-5038

Due to a lack of religious or metaphysical orientation in modern Western societies, interpersonal conflicts of interest and value are solved under the premise of individuals acting rationally through the interaction on a free market and the formation of political majorities gaining legislative power. However, the legitimacy of this approach becomes increasingly questionable when it comes to sustainability conflicts. In view of this, Hans Jonas considered the possibility of the need to suspend democratic institutions in favor of a benevolent tyrant to avert a potential catastrophe. Since any form of centralism comes with its own problems of legitimacy, utilizing the more modest orientation claims of prudence ethics is a more promising alternative in deliberations on the justifiability of an occasional suspension of the majority principle without exposing a society to the dangers of domineering arbitrariness.

\section{Demokratisches Mehrheitsprinzip in Gefahr? \\ Das Beispiel Nachhaltigkeitskonflikte}

Aufgrund fehlender religiös-metaphysischer Orientierung werden interpersonelle Interessen- und Wertkonflikte in modernen Gesellschaften unter der Prämisse rational handelnder Individuen durch die Interaktion auf freien Märkten und die Bildung politischer Mehrheiten gelöst. Dieser Ansatz sieht sich jedoch bei Nachhaltigkeitskonflikten mit Legitimationsproblemen konfrontiert. Angesichts dessen zog Hans Jonas die Möglichkeit in Betracht, dass demokratische Institutionen zugunsten eines wohlwollenden Tyrannen suspendiert werden müssten, um eine mögliche Katastrophe abzuwenden. Jede Form von Zentralismus bringt jedoch ihre eigenen Legitimationsprobleme mit sich. Deshalb ist die Operationalisierung der bescheideneren Orientierungsansprüche der Klugheitsethik eine erfolgversprechendere Alternative in Beratungen über die Rechtfertigbarkeit einer gelegentlichen Aufhebung des Mehrheitsprinzips, ohne dabei eine Gesellschaft den Gefahren herrschender Willkür auszusetzen.

Keywords: sustainability, practical philosophy, conflict management

This is an article distributed under the terms of the Creative Commons Attribution License CCBY 4.0 (https://creativecommons.org/licenses/by/4.0/)

https://doi.org/10.14512/tatup.29.3.50

Submitted: 08. 06.2020. Peer reviewed. Accepted: 21.10.2020

\section{Introduction}

Conflicts are nothing unusual for modern societies that can no longer rely on religious or metaphysical traditions to guide collective action. Democratically organized Western industrial societies deal with conflicts under the premise of purpose-rational individuals through the interplay of market events and the formation of political majorities gaining legislative power. This takes place against the background of a Constitution that guarantees basic rights for the individual, so that the inferior parties in the power struggle will not be discriminated. These in turn accept the framework of action enforced by the majority because of the possibility of being able to determine legislation in the future by forming their own majorities (Rawls 1971, pp. 390392). However, the current implementation of the majority principle reveals legitimation deficits. These are mainly due to a loss of deliberation oriented towards the common good in favor of bargaining oriented towards individual interests (Flaig 2014, pp.379-380). Especially if we look at the problem of sustainability, which is extremely broad in terms of space and time, weaknesses in this approach become apparent.

For example, the issues to be negotiated are usually so complex that it is difficult to orientate oneself towards purposeful, rational action. Furthermore, a lack of motivation for sustainable action can be identified, which is due to conflicts between short-term individual interests and long-term goals of sustainable development. In the face of such problems, the question can be asked whether majorities are justified in taking decisions against the will of minorities when it comes to issues of sustainability. Hans Jonas, for instance, expressed his concern, as early as 1979 , that a democratic majority principle might not be suitable for imposing on itself the measures that the threatening future demands (Jonas 1979, p. 262). In this context, he discusses the potential advantages of a tyranny that in our context must be a benevolent, well-informed tyranny inspired by the right insight. Even if Jonas concludes that Marxism, for him the most promising manifestation of such a regime, fails because of its utopian elements, the desire for such an "eco-dictatorship" persists stubbornly'. 
To clarify why we even bother to make decisions based on majorities, I will first briefly discuss the discourse-ethical justification of the majority principle and its application in technology assessment (TA). In view of the already mentioned problems regarding sustainability issues, I will then turn to the supposed (technical) advantages of centralized governance. Here, I will focus on the inability of such an approach to deal adequately with normative and epistemic uncertainties of sustainability issues. Having shown that an occasional suspension of majority decisions cannot be justified in this way, I will finally propose a promising alternative based on prudence-ethical arguments.

\section{The majority principle}

The majority principle is a term historically rooted in the philosophy of the state and today in political science and law. Consequently, in voting, opinion-forming processes, elections, etc., the whole is subject to the will of the greater part. The majority principle has a strong affinity for democratic structures because of the accumulation of equal votes from all those affected by a decision. In the discussion on parliamentary democracy, the absolute majority principle applied within a constitutional order was identified as the relatively closest approximation to the idea of freedom and optimal protection of even minorities (Rawls 1971). only those norms may claim validity that could find the agreement of all those concerned as participants in a practical discourse (Habermas 1986, p. 17). At the same time, the categorical imperative is reinterpreted in terms of a principle of universalization, which states that the consequences of a general adherence to a norm must be able to be accepted by everyone without compulsion. According to Habermas, the claim of universal validity of discourse ethics in the face of plural offers of orientation can be derived from the presuppositions of our language, which must always be recognized implicitly in discourse and are therefore inescapable. As stated by discourse ethicists, only those discourses that fulfil the prerequisites of communication such as freedom of domination, well-informedness, equality and so on, have the legitimatory power to generate a normative agreement.

Trying to see questions of TA as an application of discourse ethics, one encounters some difficulties as we are no longer concerned merely with controversial claims of validity with regard to the correctness of standards of action, but with the appropriateness of values (Habermas 1981, pp. 39-45). In this context, the German philosopher Konrad Ott draws attention to some particularities that require a conceptual specification of discourse ethics' basic idea (Ott 2001, pp. 53-59). As a result, in real discourses the achievement of compromises that can be accepted by the majority rather than consensus is to be expected. Therefore, a decision based on a majority principle, insofar as these (compromises) come about under discourse conditions,

\section{In real discourses the achievement of compromises that can be accepted by the majority rather than consensus is to be expected.}

From Aristotle to the French Enlightenment and Kant, there were numerous attempts to make the recourse to the majority principle in decision-making plausible. The discussion about participation and democratization after the emergence of discourse ethics gave the majority principle another boost. Since the Habermasian approach to discourse ethics has been highly influential, especially in TA since the 1990s, I want to dive a little bit deeper into the argument for the majority principle given in this line of reasoning.

Discourse ethics stands in the tradition of Immanuel Kant's moral philosophy and thus sees the nominal validity of laws or norms of action as the basic phenomenon in need of explanation. Instead of the categorical imperative, however, here the procedure of moral argumentation takes its place. Accordingly,

1 Significant authors in the past were Arne Naess, Val Plumwood, Robin Eckersley, Rudolf Bahro. Recently, such elements have been taken up in the post-growth economy (Paech 2014). appears to be the most plausible way to decide from a discourse ethicist's point of view, as it is the closest possible approximation to the ideal procedure (Renn et al. 2007, p. 180). Consequently, the evaluation of socio-technical options for action in TA is often carried out based on a multi-criteria decision analysis, which has been preceded by a discursive process that is highly influenced by Habermasian discourse ethics ${ }^{2}$.

However, when it comes to the issue of sustainability, weaknesses in this approach can be identified, especially due to the spatial and temporal extension of the respective problems. In particular, the promise that an ecologically oriented minority could determine politics or the evaluation of socio-technical options for action in the future by forming majorities becomes questionable considering the structural results of current ac-

2 An example is the recently completed Kopernikus project "ENavi", which was funded by the German government to evaluate possible coal exit paths (Gaschnig et al. 2020). 
tions, which sometimes irreversibly limit the scope for future action. This might lead to growing authoritarian tendencies, especially among young people who see their future possibility to act threatened by today's majority opinion ${ }^{3}$.

\section{The elitist approach}

Historically, an attack on the majority principle has a long tradition from Plato to Machiavelli and Tocqueville to socialist criticism. And indeed, it could be argued that, given high approval ratings for more sustainable and environmentally friendly policies (Wolf 2020), there is simply a lack of appropriate means of enforcement. From this it is then sometimes deduced in the public ecological discourse that benevolent tyrants, inspired by the right insight into our responsibility for the future, are the only possible answer to an impending environmental catastrophe. Behind all of this lies the Platonic idea, that one only needs to know the good to do good. In this context, the German philosopher of technology Christoph Hubig already reminded us in 1996, in the discussion about the so-called "Leitbild" of sustainability, of Aristotle's criticism of this way of thinking ( $\mathrm{Hu}-$ big 1996). Regarding the potential call for a government of experts, I consider it appropriate to bring this criticism to mind.

In principle, the criticism is about the idea that the recognition of a general mission statement initially yields nothing for practical implementation. Rather, we find ourselves in three further problem areas: The problem of bridging the gap, the problem of interpretation and the problem of weighing up conflicting models. In the following, I want to show this by briefly recapturing the controversy of different concepts of sustainability and their operationalization.

As mentioned above, nowadays there is a broad consensus that we have a responsibility towards future generations in respect of valuable natural resources (general mission statement). However, the matter becomes less clear with regard to the nature of this responsibility and the question of what we owe future generations to preserve (Grunwald and Kopfmüller 2012, pp. 31-75). The reason for this lies in (normative and epistemic) uncertainties that lead - unlike "conventional conflicts" - to "wicked problems" (Norton 2005, pp. 132-138) and a multitude of conflicting conceptualizations of sustainability. This problem of interpretation results from unclarified basic concepts, which are present in the general mission statement itself. The conflict between weak and strong sustainability is particularly prominent in this context $t^{4}$.

The core thesis of the weak sustainability concept is that a summative-aggregated preservation of all of society's capital

3 The environmental movement "Extinction Rebellion", for example, is said to have such tendencies.

4 It would also be possible at this point to address the discussion between the Greifswald approach of strong sustainability and the Helmholtz Association's integrative concept of sustainable development. However, I consider the chosen stocks is sufficient to fulfil the responsibility for the future. Since it is claimed that we know nothing about the preferences of future generations beyond certain basic needs and that different types of capital are fundamentally substitutable, future generations could only accuse us of lowering the level of welfare economics (Solow 1991). These assumptions are disputed by supporters of stronger sustainability concepts. A first limitation of the concept of weak sustainability is the relevance of a basic stock of natural capital that is indispensable for economic welfare. This results in the position of an ecological economy (Pearce and Barbier 2000). A further restriction of the weak sustainability concept is made from a scientific-cybernetic perspective regarding the preservation of the assimilation ability of ecological systems to changing environmental conditions as a regulator of evolution (Holling 1978). However, the concept of weak sustainability is most restricted from an environmental-ethical perspective regarding the preservation of natural capital as a necessary condition for the continuation of human autonomy and its axiological significance (Ott 2020).

The dispute about an appropriate conception of the idea of sustainable development reveals conflicts of value and shows that the good is not a generic term that can be differentiated into various class-forming sub-concepts. The fact that many things are good or bad in different ways forces us to weigh up in each concrete case (Hubig 1996, p. 230). In addition to competing views on material and non-material values, resulting from a preliminary decision in favor of a certain value theory, the first relevant question in this context is what the notion of value actually means. If different ways of speaking of value are neglected, one-sidedness of objectivist and subjectivist theories of value arise (Christen 2013, pp. 139-166), which contradict moral intuitions and thus reduce the prospect of successful conflict resolution. Furthermore, there is additional potential for conflict within a certain sustainability concept when it comes to the specification of values in criteria and indicators (Hubig 2016). This brings us to the bridging the gap problem that arises for those who want to apply a recognized principle to certain candidates.

Hubig shows in his article from 1996 that, due to normative and epistemic uncertainties, theoretically justifiable solutions for sustainability problems are not in sight and that a mechanism for their practical implementation cannot be based on unproblematic, technically justified procedures either. Therefore, ways must be developed to deal with these uncertainties. The elitist approach to sustainability problems thus lags far behind the level of reflection in the discourse-ethical debate, which explicitly recognizes the existence of a well-founded pluralism of values.

- examples to be more purposeful for my line of argument, which aims to highlight value conflicts between the concepts. Incidentally, I follow the assessment of Armin Grunwald, who considers a comparison between Greifswald and Helmholtz to be difficult, since each of these approaches seemingly tries to contribute to different discourses (Grunwald 2016, pp. 121-138). 


\section{Other orientation possibilities in view of a well-founded pluralism}

In view of orientation deficits of duty-based ethics (like discourse ethics) in dealing with concrete problems, prudence ethics tries to take a different approach. In general, prudence is the ability of an individual or institutional actor to act in a reasonable and considered manner appropriate to the situation. An actor is called prudent if he can do so even in seemingly unmanageable situations. It is also prudent to put one's own goals to the disposal, if these threaten to come into conflict with an overall good life. In contrast to the concept of prudence as the principle of rational egoism, which is often used today in ethics in dissociation from morality, this quality is an ability, which is called virtue when it has solidified into an attitude. It is the irreducible situation- and actor-specific knowledge about advice, which includes not only true and properly justified moral and legal (i.e. strongly normative) convictions, but also true and well-founded weakly normative convictions with regard to well-being or the good life. Here, of course, an 'ought to be' appears only with a hypothetical claim, as it is characteristic for the advice of prudence (Luckner 2005, pp. 39-45).

Like (material) virtue ethics, prudence ethics does not take its starting point in norm-founding procedures, but in an investigation of the self-orientation competence of individuals. It differs, however, in that it seeks to reconstruct the formal conditions of successful practice instead of referring to the virtues of a specific community of values. These conditions of successful practice were first discussed in the Aristotelian analysis of phrónesis, which is the virtue responsible for an overall good life (eu- acter of action (in an Aristotelian sense) $)^{5}$. This puts prudence ethics up against a position which is merely oriented towards functionality for the realization of certain purposes like in utility-based approaches (poiesis). Therefore, it provides important aspects of decision making, also and especially in the socio-political framework, and finds its perfection in (democratic) statesmanship that ensures that future (democratic) statesmanship remains possible (Jonas 1979, p. 214).

Consequently, discourses on the design of technology in TA must, from the perspective of prudence ethics, ensure the possibility of a dynamic continuation of the reflective equilibrium between the assessment of facts, moral intuitions, and justifications. This is realizable if higher-level values act as regulatory principles in the evaluation of socio-technical options for action that prevent internal tensions in the field of conflict from leading to contradictions (Hubig 2007, p. 150).

\section{A prudence-ethical approach}

In modern prudence ethics, majority compromises as an approximation to the discourse-ethical ideal of consensual agreement are regarded merely as a pragmatic stopgap for maintaining political peace. However, such compromises are not a genuine conflict resolution since numerous negative aspects of the competing options for action continue virulently in the agreement reached. As Hans Jonas correctly stated, this leads to legitimation problems, especially when compromises endanger the conditions of the possibility of responsible action. Instead of now demanding a benevolent and insightful elite as a solution to the

\section{Discourses on the design of technology in TA must ensure the possibility of a dynamic continuation of the reflective equilibrium between the assessment of facts, moral intuitions, and justifications.}

praxia). Although Aristotelian prudence requires general value patterns as they are found as normative frameworks in the respective cultural and historical situations, prudence itself is not bound to certain value contents. The prudent individual rather relates to certain values by considering and weighing up how the continuation of action can be guaranteed in the face of situational conflicts of values. The ethics of prudence can therefore also be described as a formal virtue ethics which forms an important actor-centered alternative to the strongly normative ethics, especially under value pluralistic conditions (Hubig 2007, pp. 127-137).

Due to its openness of content, it is also not limited to individual ethics. The basic "concepts" of prudent action, like the situational appropriateness from the perspective of maintaining and developing the ability to act, emphasize the practical char- problem of responsibility for the future and thus exposing themselves to the danger of centralist errors, prudence ethicists are focusing on the greatest possible preservation of pluralism of values, in order to preserve a society's ability to shape itself in the face of changing problems.

Prudence ethics therefore considers the prohibition of options for action justified only when risks of a particularly large extent can be avoided. ${ }^{6}$ However, we often do not have to deal

\footnotetext{
5 E. g. self-restraint in the context of sustainability.

6 Jonas argues for a similar principle when he calls for uncertainties to be treated as certainties in such cases (Jonas 1979, p. 81). The precautionary principle, which is the federal law applicable in Germany (Art. 34 Abs.1 EV, Einigungsvertrag), can be read in a similar way. The respective basic intention is that the treatment of uncertainty itself is not in itself uncertain but is both a prudent advice and (in this case) an undeniable imperative.
} 
with decisions of such magnitude when it comes to sustainability conflicts. Therefore, further situation-dependent strategies are needed to deal with well-founded dissent about the design of sustainable development. In this context, Christoph Hubig has proposed some strategies for dealing with dissent ${ }^{7}$ in his major ethical work (Hubig 2007, pp. 147-163), which coincide with what is known as "adaptive management" in the sustainability discourse (Walker et al. 2013; Kwakkel et al. 2016).

It is necessary to consider higher-level values in the evaluation of socio-technical options of action to preserve the conditions for such a prudent approach at the individual and institutional level. The consideration of these option and bequest values (Hubig 2007, pp. 137-146), which are intended to enable cal for modern societies, difficult. Where the usual utility-oriented procedures for dealing with these conflicts are still used, a loss of acceptance and post-democratic tendencies can be observed due to the lacking legitimacy of decisions reached in this way. However, the solution to install benevolent tyrants, who, inspired by the right insight, make decisions guided by a wellfounded responsibility for the future, brings along serious problems. In view of various forms of non-knowledge regarding future developments, there is a danger of centralistic errors that could lead to far worse conditions than those currently prevailing. In any case, the striving for consensus as a guarantee for the possibility of purpose-rational action at the societal level proves to be an unredeemable claim in most sustainability issues. Thus,

\section{Orientation towards prudence ethics aims to preserve the conditions of the possibility of practice as such.}

decision-making individuals and institutions, need not be legitimized by a majority within a discursive process, but can be subjected to each person willing to act. The estimation of the potential endangerment of criteria that enable a decision-maker to establish a self-determined relation to a situation must therefore be included and spelled out in TA practice in any specific case. Accordingly, from a prudence-ethical point of view, the avoidance of systematic constraints, the avoidance of restrictions on actors and decision-making capabilities, as well as the preservation of revisability and compensability must become a central value in the design of socio-technical systems. If these process-oriented criteria remain a matter of subjective value assessments of discourse participants in multi-criteria decision analyses in TA there is a danger to the possibility of acting in accordance with a well-funded precautionary principle and thus jeopardize the conditions of the possibility of responsible action (Kornwachs 2000). A good example for such a problem is the development of the transport system in Germany: With regard to these higher-level values and criteria, there never should have been such a one-sided, coercive transport policy which is now hardly able to react to uprising problems like climate change, lack of urban space, noise pollution, etc. (Bangert 2017).

\section{Conclusion}

I demonstrated that sustainability conflicts are characterized by normative and epistemic uncertainties. In most cases, this makes purpose-oriented conflict management, which is typi-

7 These rules for dealing with dissent are in accord with the tradition of René Descartes' provisional morality. He drafted his maxims in the face of the abolition of traditional instances of orientation in the early $17^{\text {th }}$ century, so that he would not remain indecisive in his actions, while reason obliged him to be so in his judgments (Descartes 1637/2011, p. 41). competing social technologies for dealing with conflicts should not be evaluated on this basis.

In the spirit of a provisional morality, however, we can reflect on the limits of our power to act and envisage rules that should enable good action despite the uncertain decision-making situation. Here, the orientation towards prudence ethics reveals itself as a promising alternative, since it does not come up with the problematic universality claim of moral and technical imperatives, but rather aims to preserve the conditions of the possibility of practice as such (Luckner 2005, pp. 39-45). This results in process-oriented criteria beyond utility values that can be used to evaluate techniques for dealing with sustainability conflicts.

Criteria such as flexibility, error-friendliness, compensability, reversibility, transparency, or the avoidance of constraints speak in favor of conflict management on the basis of democratic institutions and against any form of centralism (Ott 2014). In short, this defines the preservation of the capacity to act. However, discourse boundaries in the form of a restriction of democratic participation and decision-making must be observed to prevent counterintuitive results of decisions made by the majority. The justification of these limits based on the prudence-ethical principle of the preservation of practice comes with fewer difficulties than strategies of justification based on duty-oriented ethics and utilitarianism. In conclusion, the appropriate response to a swan song for democratic institutions in the face of an impending climate catastrophe and comparable dangers would be the foundation and/or strengthening of institutions which ensure the possibility of future (democratic) statecraft ${ }^{8}$.

8 If these institutions already exist as deliberative intermediate realms (Ott 2014) - including the practice of technology assessment - or whether they must first be created as environmental councils (Gesang 2014) must be clarified elsewhere. 


\section{References}

Bangert, Armin (2017): Kriterien technischer Akzeptabilität am Beispiel des Verkehrs in urbanen Lebensräumen. Darmstadt: Technische Universität Darmstadt.

Christen, Marius (2013): Die Idee der Nachhaltigkeit. Eine werttheoretische Fundierung. Marburg: Metropolis.

Descartes, René (1637/2011): Discours de la méthode. Hamburg: Felix Meiner.

Flaig, Egon (2014): Die Mehrheitsentscheidung. Ihre kulturelle Bedeutung. In: Erwägen Wissen Ethik 2014 (3), pp. 369-381.

Gaschnig, Hannes et al. (2020): Multikriterielle Bewertung der Energiewende. Nachhaltigkeitsprofile zum Kohleausstieg. ENavi-Abschlussbericht des Arbeitspaketes 11 für den Schwerpunkt „Transformation des Stromsystems“. Potsdam: Institute for Advanced Sustainability Studies (IASS).

Gesang, Bernward (2014): Demokratie am Scheideweg. In: Bernward Gesang (ed.): Kann Demokratie Nachhaltigkeit? Wiesbaden: Springer VS, pp. 19-40. DOI: 10.1007/978-3-658-04895-2_2.

Grunwald, Armin (2016): Nachhaltigkeit verstehen. Arbeiten an der Bedeutung nachhaltiger Entwicklung. Munich: oekom.

Grunwald, Armin; Kopfmüller, Jürgen (2012): Nachhaltigkeit. Frankfurt am Main: Campus.

Habermas, Jürgen (1981): Handlungsrationalität und gesellschaftliche Rationalisierung. Frankfurt am Main: Suhrkamp.

Habermas, Jürgen (1986): Moralität und Sittlichkeit. Treffen Hegels Einwände gegen Kant auch auf die Diskursethik zu? In: Wolfgang Kuhlmann (ed.): Moralität und Sittlichkeit. Das Problem Hegels und die Diskursethik. Frankfurt am Main: Suhrkamp, pp. 16-37.

Holling, Crawford (1978): Adaptive environmental assessment and management. Chichester: John Wiley.

Hubig, Christoph (1996): Nachhaltigkeit als Problem angewandter Technikethik. In: Hans-Peter Böhm (ed.): Nachhaltigkeit als Leitbild für Technikgestaltung. Dettelbach: Röll, pp. 225-242.

Hubig, Christoph (2007): Die Kunst des Möglichen II. Ethik der Technik als provisorische Moral. Bielefeld: Transcript. DOI: http://dx.doi.org/10.14361/ 9783839405314

Hubig, Christoph (2016): Indikatorenpolitik. Über konsistentes und kohärentes kommunikatives Handeln von Organisationen und in Unternehmen. Wiesbaden: CSSA Chemie-Stiftung Sozialpartner-Akademie.

Jonas, Hans (1979): Das Prinzip Verantwortung. Versuch einer Ethik für die technologische Zivilisation. Frankfurt am Main: Insel Verlag.

Kornwachs, Klaus (2000): Das Prinzip der Bedingungserhaltung. Eine ethische Studie. Münster: LIT Verlag..

Kwakkel, Jan; Walker, Warren; Haasnoot, Marjolijn (2016): Coping with the wickedness of public policy problems. Approaches for decision making under deep uncertainty. In: Journal of Water Resources Planning and Management 142 (3). DOI: 10.1061/(ASCE)WR.1943-5452.0000626.

Luckner, Andreas (2005): Klugheit. Berlin: De Gruyter. DOI: 10.1515/9783110898309.122

Norton, Bryan (2005): Sustainability. A philosophy of adaptive ecosystem management. Chicago: University of Chicago Press.

Ott, Konrad (2001): Zum Verhältnis von Diskursethik und diskursiver Technikfolgenabschätzung. In: Barbara Skorupinski and Konrad Ott (eds.): Ethik und Technikfolgenabschätzung. Beiträge zu einem schwierigen Verhältnis. Basel: Helbing \& Lichtenhahn, pp. 30-68.
Ott, Konrad (2014): Deliberative Zwischenreiche und Umweltpolitik. In: Annual Review of Law and Ethics: Foundation and Limitation of Solidarity in Law and Ethics (22), pp. 289-312.

Ott, Konrad (2020): Umweltethik. In: Online Encyclopedia Philosophy of Nature, 2019. DOI: $10.11588 /$ OEPN.2020.0.68742.

Paech, Niko (2014): Postwachstumsökonomie als Abkehr von der organisierten Unverantwortlichkeit des Industriesystems. In: Robert Pfaller and Klaus Kufeld (eds.): Arkadien oder Dschungelcamp. Leben im Einklang oder Kampf mit der Natur? Freiburg: Alber, pp. 217-247.

Pearce, David; Barbier, Edward (2000): Blueprint for a sustainable economy. London: Routledge.

Rawls, John (1971): A theory of justice. Cambridge (Massachusetts): Belknap Press of Harvard Univ. Press.

Renn, Ortwin; Deuschle, Jürgen; Jäger, Alexander; Weimer-Jehle, Wolfgang (2007): Leitbild Nachhaltigkeit. Eine normativ-funktionale Konzeption und ihre Umsetzung. Wiesbaden: Springer VS. DOI: 10.1007/978-3-531-90495-5.

Solow, Robert (1991): Sustainability: An economist's perspective. Woods Hole (Massachusetts): Woods Hole Oceanographic Institution.

Walker, Warren; Haasnoot, Marjolijn; Kwakkel, Jan (2013): Adapt or perish. A review of planning approaches for adaptation under deep uncertainty. In: Sustainability 5 (3), pp. 955-979. DOI: 10.3390/su5030955.

Wolf, Ingo (2020): Soziales Nachhaltigkeitsbarometer der Energiewende 2019. Potsdam: Institute for Advanced Sustainability Studies (IASS).

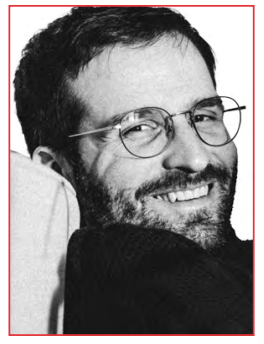

\section{ARMIN BANGERT}

has been a researcher at the Institute for Technology Assessment and Systems Analysis in Karlsruhe since 2017. He is a member of the Research Group "Philosophy of Engineering, Technology Assessment, and Science". His work evolves around applied ethics in the field of sustainability with a focus on mobility. 